STANISŁAW CHROBAK

Uniwersytet Kardynała Stefana Wyszyńskiego

w Warszawie

\title{
WYCHOWANIE ODPOWIEDZIALNEGO OBYWATELA W PERSPEKTYWIE SYSTEMU PREWENCYJNEGO ŚW. JANA BOSKO
}

\section{EDUCATING THE RESPONSIBLE CITIZEN FROM THE PERSPECTIVE OF ST. JOHN BOSCO'S PREVENTIVE SYSTEM}

\section{Streszczenie}

Jan Bosko dostrzegał wychowanie w szerokim kontekście rodziny, społeczeństwa, państwa i Kościoła. Był przekonany, że pozbawiony elementów religii klimat wychowawczy nie może sprzyjać ogólnemu rozwojowi młodzieży. Połączone z wymogami „rozumu” wymogi ,serca” (miłość wychowawcza) i „religii” splatają się w niepowtarzalną i jedyną całość. Wychowawcza obecność w wymiarze społecznym - według słów Jana Bosko - ma zmierzać do formowania «uczciwych obywateli i dobrych chrześcijan», tzn. osób twórczych, aktywnych i odpowiedzialnych, świadomych swej godności, mających programy życia, otwartych na transcendencję, na drugich i na Boga. Zatem, w projekcie jego wychowania, nie ma sprzeczności między byciem obywatelem i byciem chrześcijaninem, bo zaangażowany chrześcijanin jest - lub powinien być - dobrym, odpowiedzialnym i uczciwym obywatelem.

\section{Słowa kluczowe}

System prewencyjny, wychowanie, odpowiedzialny obywatel. 


\begin{abstract}
John Bosco saw education in the broad context of the family, society, Church and state. He was convinced that an educational climate devoid of elements of religion could not favour the young person's overall development. Combined with the requirements of "reason", the requirements of the "heart" (educational love) and "religion" are interwoven in an inimitable and unique whole. Educational presence in the social dimension - in the words of John Bosco - is to strive for the formation of "honest citizens and good Christians", i.e. creative, active, responsible people who are conscious of their dignity, with life plans, open to transcendence, to others, and to God. Thus, the design for his upbringing contains no contradiction between being a citizen and being a Christian, because the engaged Christians is - or should be - a good, responsible and honest citizen.
\end{abstract}

\title{
Key words
}

Preventive system, education, responsible citizen.

\section{WPROWADZENIE}

Pojęcie obywatelstwa zmieniało się znacząco w ciagu wieków, a obywatelom przypisywano różne prawa i obowiązki. Także dziś definicja obywatelstwa nie jest jednoznaczna. Często używa się jej w znaczeniu prawnym, oznaczającym obywatelstwo narodowe. Pojęcie obywatelstwa $\mathrm{w}$ dyskursie politycznym związane jest z pojęciem tożsamości kulturowej i narodowej. Historycznie obywatelstwo związane zostało z poczuciem tożsamości, z pewnym etosem oraz zespołem cnót, takich jak lojalność, odpowiedzialność, braterstwo, szacunek dla wartości narodowych i społecznych. Aktywność obywatelska to nie tylko kwestia praw i obowiązków jednostki wobec państwa, lecz także szeroko rozumiane uczestnictwo w życiu społecznym. Historyczna zmienność form życia politycznego zyskuje nowy wymiar w dobie postępującej globalizacji, w której pojawiają się takie czynniki, jak liberalizacja życia poli- 
tycznego, wzrost znaczenia międzynarodowych korporacji, otwarcie na kontakty międzynarodowe, intensywna komunikacja i interaktywność w skali całych społeczeństw. Pojęcie obywatelstwa jest także zasadą organizującą społeczeństwa uczącego się. ${ }^{1}$

Obywatelska postawa nierozerwalnie powinna wiązać się z odpowiedzialnością - poczuciem odpowiedzialności. Pojęcie odpowiedzialności ujawnia, że człowiek będący podmiotem odpowiedzialności jest źródłem oceny moralnej własnych czynów, wypowiedzi, zachowań oraz uczestnikiem sytuacji i zdarzeń, w których uczestniczą też inne osoby. Staje się „kimś” i ,jakimś” przez swoje czyny, przez działanie świadome, a różne formy aktywności powodują ciagłe ubogacanie osoby. Poprzez swoje czyny, (działanie świadome), staje się dobrym lub złym w znaczeniu moralnym. W strukturze stawania się człowieka moralnie dobrym lub złym, przez jego czyny, unaocznia się wolność. Wolność utożsamia się z samostanowieniem, z konkretnym «ja chcę», «mogę nie muszę». ${ }^{2} \mathrm{~W}$ odpowiedzialności ujawnia się osoba spełniająca czyn i zarazem spełniająca siebie przez ten czyn. „Ujęcie sprawczości podmiotu działającego w stosunku do jego działania łączy się ściśle z ujęciem odpowiedzialności za działanie, co dotyczy nade wszystko zawartości aksjologicznej i etycznej czynu. To wszystko wchodzi niejako organicznie w doświadczenie samostanowienia."3 Wolność podmiotu

${ }^{1}$ Por. D. Dańkowski, Obywatel, [w:] Stownik społeczny, red. B. Szlachta, Kraków 2004, s. 765-775; E. Potulicka, Edukacja dla demokracji, [w:] Wychowanie. PojęciaProcesy - Konteksty. Interdyscyplinarne ujęcie, t. 2, red. M. Dudzikowa, M. CzerepaniakWalczak, Gdańsk 2007, s. 85-87.

2 Por. K. Wojtyła, Osoba: podmiot i wspólnota, [w:] tenże, Osoba i czyn oraz inne studia antropologiczne, Lublin 1994, s. 425-426; „Odpowiedzialne obywatelstwo oznacza aktywność członków społeczności politycznej, świadomych przede wszystkim swej przynależności do wspólnoty ludzkiej, którzy już w swoich osobistych wyborach, stylach życia, udziale w kulturze wyrażają i realizują pewną ideę społeczeństwa. Ponadto wchodzą $\mathrm{w}$ interakcję z czynnikami rządowymi i władzami: nie tylko są adresatami działań rządowych, ale tymi, od których zależą decyzje podejmowane na górze i którzy przez działania polityczne kontrolują i weryfikują poczynania rządu" (F. Appi, Wiara - świeckość - obywatelstwo, tłum. T. Żeleźnik, „Społeczeństwo” 2006, nr 4-5, s. 654).

${ }^{3}$ K. Wojtyła, Osobowa struktura samostanowienia, [w:] tenże, Osoba i czyn..., dz. cyt., s. 383-387; tenże, Podmiotowość $i$,,to, co nieredukowalne” w człowieku, [w:] 
odpowiedzialności oznacza, iż czynem, za który jest on odpowiedzialny, jest jego własny czyn podjęty świadomie i dobrowolnie.

Istotnym aspektem w całokształcie tej rzeczywistości, jaką stanowi odpowiedzialność, jest „odpowiedzialność przed”. Jest to zawsze odpowiedzialność „,przed kimś” - a więc przed osobą. Świat osób ma swą strukturę międzyludzką oraz strukturę społeczną. Odpowiedzialność „przed kimś”, kształtuje się także i wyraża w odniesieniu do własnego podmiotu. Owym „kimś”, przed którym jestem i czuję się odpowiedzialny, jest moje własne ,ja”. Jeżeli człowiek jako osoba jest tym, który sam siebie posiada i sam sobie panuje, to także dlatego, że sam za siebie i przed sobą odpowiada. Struktura odpowiedzialności jest naprzód właściwa osobie od wewnątrz, na zasadzie zaś uczestnictwa - wspólistnienia i współdziałania z innymi - staje się odpowiedzialnością przed „kimś”, gdy człowiek żyje i działa wspólnie z innymi ludźmi. Tutaj w grę wchodzi pojęcie współodpowiedzialności związanej z aktywnym współudziałem w życiu określonej wspólnoty. Nie chodzi tutaj jednak o wielość działań, które niejako przebiegają obok siebie. Wspólnie oznacza, że działania te, a wraz z nimi i bytowanie owych wielu ,ja” pozostają w relacji do jednej jakiejś wartości, która przez to zasługuje na nazwę dobra wspólnego. Relacja wielu ,ja” do dobra wspólnego stanowi sam rdzeń wspólnoty społecznej oraz jednoczy wielość podmiotów w jedno „my”. Także w ramach tej struktury odpowiedzialność „przed kimś" możemy również mówić o odpowiedzialności przed Bogiem. Jest to odpowiedzialność w znaczeniu eschatologicznym, ale i doczesnym zarazem. ${ }^{4}$ Zatem kształtowanie poczucia odpowiedzialności powinno

tenże, Osoba $i$ czyn..., dz. cyt., s. 440-441. „Im większa jest świadomość działania oraz świadomość wartości, tym wyraźniej człowiek - podmiot przeżywa samostanowienie. Im wyraźniej zaś przeżywa samostanowienie, tym jaśniej w przeżyciu i w świadomości rysuje się własna sprawczość i odpowiedzialność. Samostanowienie stanowi istotę wolności człowieka”. (K. Wojtyła, Osobowa struktura..., dz. cyt., s. 426-427).

4 Por. K. Wojtyła, Osoba i czyn..., dz. cyt., s. 214-216; tenże, Osoba: podmiot..., dz. cyt., s. 403-404. „Odpowiedzialność za ludzki czyn zakłada zawsze poczytalność tego czynu, poczytalność zaś implikuje jego rozumność (...) z tej zaś rodzi się szczególny związek aktu z osobą, zwany odpowiedzialnością". (T. Ślipko, Zarys etyki ogólnej, Kraków 1974, s. 385. 
być również jednym z głównych celów wszelkiego rozumnego wychowania oraz kształtowania charakteru i osobowości.

\section{ROZUM, RELIGIA, MILOŚĆ WYCHOWAWCZA - PODSTAWOWE ZASADY SYSTEMU PREWENCYJNEGO JANA BOSKO}

„Istnieją dwa systemy - pisał Jan Bosko (1815-1888) - jakie zawsze stosowano $\mathrm{w}$ wychowaniu młodzieży: prewencyjny i represyjny. (...) System prewencyjny polega na tym, że podwładnych zaznajamia się z przepisami i regulaminem zakładu, a następnie roztacza się nad nimi taką opiekę, że wychowankowie znajdują się zawsze pod czujnym okiem dyrektora lub asystentów, którzy jako kochający ojcowie przemawiają do nich, w każdej okoliczności służą im za przewodników, udzielają rad i upominają z dobrocią, co jest równoznaczne z postawieniem wychowanków w niemożności popełnienia wykroczeń." 5 System prewencyjny Jana Bosko stanowi zwarty i spójny system wychowawczy o określonych celach i zadaniach. System ten powstał jako odpowiedź na potrzeby wychowawcze związane z konkretnym środowiskiem XIX wieku we Włoszech. Użyteczność systemu prewencyjnego w naszych czasach nie domaga się niewolniczego powtarzania tego, co robił ks. Bosko i ci wszyscy, którzy inspirowali się jego dziełem. Wymaga on raczej odwagi naśladowania ks. Bosko w zmieniającym się obecnie kontekście społeczno-historycznym.

Projekt wychowania św. Jana Bosko konkretyzują trzy podstawowe zasady (kategorie) ujęte w trójmian: rozum, religia, miłość wychowawcza.

- „rozum” - termin ten zgodnie z autentyczną wizją chrześcijańskiego humanizmu podkreśla godność osoby oraz zdolność towarzyszenia i pokierowania młodzieżą w wędrówce ku pełnemu życiu, do którego dochodzi się dzięki jasności poglądów i bezustannemu poszukiwaniu prawdy w wolności. „Rozum” w tym kontekście oznacza także

\footnotetext{
5 J. Bosko, System prewencyjny w wychowaniu młodzieży, [w:] Wspótczesny wycho-
} wawca..., dz. cyt., s. 213-214. 
rozsądek, prostotę, naturalność, przyjacielskość, gotowość do dialogu i uznanie konieczności, by wychowanek w miarę swych możliwości dokonywał wyborów i podejmował decyzje. „Rozum” zapoczątkowuje cały proces wychowania - najpierw wychowanek musi wiedzieć, co ma robić, a potem należy mu pomóc o tym pamiętać, by rozumne myślenie stało się cechą wychowanka, przekształcając się w świadomość faktycznej osobistej odpowiedzialności. Ponadto współczesny nauczyciel-wychowawca powinien umieć uważnie odczytywać znaki czasu, by móc dostrzec pojawiające się wartości, które interesują młodzież;

- „religia” - wskazuje, ze pedagogia księdza Bosko jest w swej istocie transcendentna, ponieważ ostatecznym celem wychowawczym jest ukształtowanie człowieka wierzącego. W jego rozumieniu człowiek uformowany i dojrzały to wierzący obywatel, taki, który swoje życie koncentruje wokół obwieszczonego przez Jezusa Chrystusa ideału człowieka nowego i który odważnie wyznaje swoje przekonania religijne. Ksiądz Bosko widział w religii rolę syntetyzującą wychowanie. Rozumność życia religijnego przejawia się między innymi w tym, że unika się redukowania religii do sfery tylko przeżyć, jaki i odwrotnie do sfery rozumu i nauczania reguł, zasad i definicji. W rozumnym podejściu do religii dąży się do wyjaśnienia sensu nauczanych prawd religijnych i ich praktykowania w codziennym życiu. Wobec powyższego tak rozumiana zasada (kategoria) oznacza wiarę żywą, zakorzenioną w rzeczywistości a nie jakąś religię spekulatywną i abstrakcyjna;

- „miłość wychowawcza” - miłość rozpatrywana w klimacie rozumu i religii oznacza przede wszystkim poszanowanie młodego człowieka. Jest to sposób bycia wyrażający sympatię, zrozumienie, współczucie, zaufanie, współuczestnictwo w życiu drugiego człowieka. Oparte na miłości wychowanie nie polega na uleganiu wszelkim zachciankom, ale na działaniu sprzyjającym asymilacji tych wartości, które stanowią podstawę bycia «dobrym chrześcijaninem i uczciwym obywatelem». Okazywana miłość, to miłość ludzka, mądra, odrzucająca chorobliwą przesadę sprowadzającą człowieka do roli instru- 
mentu. Miłość wychowawcza ma prowadzić wychowanka ku pełnej dojrzałości i samodzielności. Jest uczuciem bezwarunkowym. Realizacja tak rozumianej „miłości wychowawczej” jest dla księdza Bosko w pierwszym rzędzie miłością ewangeliczną i opiera się całkowicie na słowach św. Pawła: «miłość cierpliwa jest..., wszystko znosi..., we wszystkim pokłada nadzieję..., wszystko przetrzyma... (por. 1 Kor 13,4-7)». Miłość wychowawcza to przede wszystkim świadomość odpowiedzialności i gotowość uczestniczenia w niej. ${ }^{6}$

Działalność wychowawcza księdza Bosko miała swój początek w latach czterdziestych XIX wieku. W 1841 roku na Valdocco (przedmieścia Turynu), dzięki znajomości ówczesnej sytuacji oraz na podstawie doświadczenia innych (m. in. św. Filipa Nereusza i św. Karola Boromeusza) stworzył ideę Oratorium. ${ }^{7}$ Dzieło Oratoriów rozpoczęte od ,prostej katechezy”, odpowiadając na wymogi i naglące sytuacje przybrało formę schroniska dla bezdomnych, warsztatów, szkół zawodowych uczących pracy oraz samodzielnego i uczciwego zarabiania na życie, szkół typu humanistycznego, różnego rodzaju inicjatyw i metod rozrywki odpowiadających epoce (teatr, orkiestra, śpiew, wycieczki). Idea Oratorium jest wyznacznikiem całej jego działalności, której celem było wychować «uczciwych obywateli i dobrych chrześcijan». ${ }^{8}$

W klimacie pedagogicznej obecności - stwierdza ksiądz Bosko - ważne są przede wszystkim relacje osobowe. Obecność nauczycie-

\footnotetext{
${ }^{6} \mathrm{Na}$ ten temat zobacz m. in.: L. Cian, System zapobiegawczy św. Jana Bosko i charakterystyczne rysy jego stylu, thum. M. Gabryel, Warszawa 1986; L. Cian, Wychowanie w duchu Księdza Bosko, tłum. I. Gutewicz, Warszawa 1990; R. Weinschenk, Podstawy pedagogiki Księdza Bosko, tłum. J. Jurczyński, Warszawa 1996; C. Bissoli, Jan Pawet II o systemie wychowawczym księdza Bosko, tłum. K. Misiaszek, Warszawa 2001.

7 Dzieło Oratorium - rozpoczęte przez Jana Bosko w 1841 roku - należy rozumieć w kategoriach środowiska wychowawczego, dającego wychowankom możliwość ludzkiego i chrześcijańskiego rozwoju. Od samego początku zakłada się, że ma być ono: „,domem, który przygarnia; parafia, która ewangelizuje; szkołą, która przygotowuje do życia i podwórkiem, gdzie spotykają się przyjaciele i żyje się radośnie" (Konstytucje Towarzystwa św. Franciszka Salezego, Rzym 1986, n. 40.).

8 Por. J. Bosko, System prewencyjny w wychowaniu młodzieży, [w:] Współczesny wychowawca w stylu księdza Bosko, red. J. Wilk, Lublin 1998, s. 218; F. Casella, L'esperienza educativa preventiva di don Bosco. Studi sull'educatione salesiana fra tradicione e modernità, Roma 2007, s. 13-23.
} 
la-wychowawcy wśród młodzieży, uczestnictwo w jej życiu jest integralną częścią procesu wychowania. Ksiądz Bosko, ilekroć mówi o wychowaniu, ma zawsze na myśli kontakt międzyosobowy, który znaczy więcej niż przypadkowe spotkanie. Obecność wychowawcy w rozwoju wychowanka nazywa ,asystencja”. Oznacza zawsze, że wychowawca jest w pełni z wychowankiem, uczestniczy w jego życiu, interesuje się nim, okazuje mu szacunek. Uczył, wychowując i wychowywał, ucząc. Zarówno nauczanie, jak i wychowanie były dla niego ukierunkowane na przygotowanie wychowanka do samodzielnego i odpowiedzialnego życia. Dla młodych ludzi był nie tylko kapłanem-pasterzem, ale ojcem i mistrzem, który pobudzał ich rozwój, towarzyszył w pracy, uczył jak spędzać czas wolny od pracy i nauki. Zawsze był sobą i to, co pokazywał, było odbierane jako «prawdziwe» i «autentyczne», cieszył się wielkim zaufaniem. ${ }^{9}$ Tymi ideami były nasycone zarówno organizacja codziennego życia, sposoby działania, wzorce zachowania, jak i codzienna praktyka. W ten sposób środowisko stawało się wychowawcze, stawało się jednocześnie narzędziem i miejscem wychowania.

\section{SYSTEM PREWENCYJNY - WYCHOWANIE INTEGRALNE MLODZIEŻY}

Także dzisiaj prewencyjny system Jana Bosko może stanowić podstawę dla wszystkich zajmujących się pracą wychowawczą. Ks. Bosko wychowawca nie proponuje gotowych recept, ale wzywa do dokonania przemyślanych działań w obszarze wychowania, które nie zakładają bezpośrednio przenoszenia stosowanych przez niego metod, ale przede wszystkim zwracają uwagę na aktualny i dobrze rozpoznany kontekst kulturowy. Zatem w konfrontacji z potrzebami dzisiejszej młodzieży,

\footnotetext{
9 Por. U. Fontana, Relacja sekretem wszelkiego wychowania, thum. J. Krykowski, Warszawa2002, s. 85-88. „Ksiądz Bosko stworzył szkołę wychowania i był w niej mistrzem, mistrzem w nawiązywaniu kontaktów z wychowankami, w uczestnictwie w ich życiu i w ich drodze formacyjnej. Był mistrzem pewnym oraz posiadającym zdolność dodawania odwagi innym. Jeżeli dołączymy do tego fakt, że ksiądz Bosko przeżył osobiście to, co potem starał się zrobić dla młodzieży, to można bez obawy twierdzić, że był, i wciąż jest mistrzem wiarygodnym". (C. Bissoli, dz. cyt., s. 48.).
} 
można wskazać na następujące zagadnienia, których znajomość dzisiaj jest nieodzowna dla rozumienia sytuacji młodzieży oraz dla skutecznego działania wychowawczego:

1. stan biedy i nierówności społecznej jako czynniki ograniczające, a nawet uniemożliwiające współczesne wychowanie;

2. rozwój informatyki i komunikacji społecznej;

3. gwałtowny rozwój technologiczny oraz związana z nim nowa kultura życia;

4. skażenie środowiska i zagrożenia nuklearne, podejmowane w aspekcie uświadomienia sobie granic ludzkiej działalności;

5. właściwe rozumienie erotyzmu i miłości;

6. dialog międzykulturowy, który niesie ze sobą nową perspektywę życia;

7. dialog międzyreligijny oraz nowe doświadczenia kontaktu z Bogiem. ${ }^{10}$ Kwestie te z pewnością nie tworzą wyczerpującego obrazu problematyki młodzieżowej, ile raczej uprzytamniają nam potrzebę prowadzenia szerokich badań na temat sytuacji młodych ludzi w dzisiejszym świecie. Jest to lektura kontekstu i warunków życia dzisiejszej młodzieży w perspektywie wychowawczej. Każdy wychowawca powinien stawiać sobie pytania: „Kim są młodzi? Czego pragną? Do czego dążą? Jakie mają potrzeby? Są to pytania dotyczące tożsamości, woli, pragnień, potrzeb młodzieży. Odnoszą się do wymiaru życia osobistego i społecznego młodych, do ich aspiracji i potrzeb, również do ich marzeń i decyzji. I ta «pedagogia pytań» jest bardzo potrzebna w refleksji wychowawczej, aby propozycje czynione przez wychowawcę młodym nie okazywały się ani od nich dalekie, ani wymuszone, ale wpływały na lepszą ich znajomość: «Wiem, kim jesteś, czego pragniesz, jakie są twoje nie tylko pragnienia, ale i rzeczywiste potrzeby»." 11 System prewencyjny w kon-

\footnotetext{
${ }^{10}$ Por. J. E. Vecchi, Strażnicy marzeń z palcem na myszce. Wychowawcy $w$ dobie informatyki, thum. A. Lis, Warszawa 2001, s. 63-141.

${ }^{11}$ C. Bissoli, dz. cyt., s. 58. „Prawdziwy wychowawca uczestniczy więc w życiu młodzieży, interesuje się jej problemami, stara się poznać jej zapatrywania, uczestniczy w jej życiu sportowym i kulturalnym, w jej rozmowach; jako dojrzały i odpowiedzialny przyjaciel wskazuje dobre cele i drogi do ich osiagnięcia, jest gotów wyjaśniać problemy i wskazywać kryteria, by z roztropnością i życzliwą stanowczością poprawiać oceny
} 
frontacji z potrzebami dzisiejszej młodzieży skłania do bycia odważnymi w działaniu, do ważnych wyborów, do przyjmowania sposobów i form wychowawczych użytecznych w promowaniu i stymulowaniu pozytywnych energii młodzieży, jej głębokich aspiracji, konkretnych historycznych możliwości rozwoju.

Wychowanie nie może być ograniczone tylko do „zawodu” lub też do roli społecznej, przeżywanej bez głębszego zaangażowania i bezpośredniego zainteresowania. Wychowanie staje się czymś, co organizuje i integruje całe życie. „Ks. Bosko i system prewencyjny sprzyjali aktywnej roli młodego człowieka. A zatem wychowawca, jakkolwiek kiedyś posiadał znaczącą rolę kierowniczą, zgodną z ideą czasu, w systemie ks. Bosko przedstawia się jako ten, którego nazywamy asystentem: nie asystentem dyscyplinarnym, ale towarzyszem. (...) Chciał powiedzieć, że edukacja nie jest wyłącznie kwestią narzucania niechętnie lub nawet dobrowolnie wypełnianych przyjętych reguł, ale że musimy dotrzeć do istoty odczuwania każdego młodego człowieka." ${ }^{12}$ System ten zespala drogi życiowe wychowawców i młodzieży w rodzinnym klimacie zaufania i dialogu. Zaufanie, miłość i serdeczna współpraca są - zdaniem turyńskiego wychowawcy - warunkiem każdej autentycznej relacji wychowawczej. Tym samym w działaniu pedagogicznym ks. Bosko formułuje zasadę, że: „w każdym młodym człowieku, nawet najbardziej zaniedbanym, istnieje jakiś punkt dostępny dla dobra, a wtedy pierwszym obowiązkiem wychowawcy jest poszukiwanie tego punktu, tej wrażliwej struny, i budowanie na niej." 13 Właściwym dla niego spo-

i postępowanie zasługujące na naganę. W takim klimacie «pedagogicznej obecności» wychowawca nie jest uważany za «przełożonego», lecz za «ojca, brata i przyjaciela»". (Jan Paweł II, List „Juvenum patris” w setnq rocznicę śmierci św. Jana Bosco, Rzym, Tipografia Poliglotta Vaticana 1988, n. 12.).

12 J. E. Vecchi, Strażnicy marzeń..., dz. cyt., s. 148-150. „Czego więc potrzeba? Żeby chłopcy nie tylko byli kochani, ale żeby oni sami poznali, że są kochani. (...) Trzeba, aby czując, że są kochani w tym, co im sprawia przyjemność, i widząc, że się uczestniczy w ich młodzieńczych upodobaniach, nauczyli się dostrzegać miłość również w sprawach, które z natury mniej się podobają jak: karność, nauka, umartwienie samych siebie". (Jan Bosko, List z Rzymu, w: Współczesny wychowawca..., dz. cyt., s. 224.).

13 C. Bissoli, dz. cyt., s. 69. „Dzisiaj bardziej niż kiedykolwiek potrzebna jest akceptacja osób takimi, jakimi są i jakimi «imiennie» mogą być ucząc się planowania i wery- 
sobem postępowania było okazywanie wychowankowi zaufania, które stawało się zarazem bodźcem do dalszego rozwoju.

\section{AKTYWNY I ODPOWIEDZIALNY OBYWATEL W ROZUMIENIU PEDAGOGIKI JANA BOSKO}

Wychowawcza obecność w wymiarze społecznym - według słów Jana Bosko - ma zmierzać do formowania „«uczciwych obywateli i dobrych chrześcijan», tzn. osób twórczych, aktywnych i odpowiedzialnych, świadomych swej godności, mających programy życia, otwartych na transcendencję, na drugich i na Boga."14 Jan Bosko dostrzegał wychowanie w szerokim kontekście rodziny, społeczeństwa, państwa i Kościoła. Był przekonany, że pozbawiony elementów religii klimat wychowawczy nie może sprzyjać ogólnemu rozwojowi młodzieży. Połączone z wymogami „rozumu” wymogi „serca” (miłość wychowawcza) i „religii” splatają się w niepowtarzalną i jedyną całość. Zatem w projekcie jego wychowania nie ma sprzeczności między byciem obywatelem i byciem chrześcijaninem, bo zaangażowany chrześcijanin jest - lub powinien być - dobrym, odpowiedzialnym i uczciwym obywatelem. W tym też kontekście, zwracając uwagę na wartość życia społecznego i międzyludzkiego, służył dobru ubogiej i opuszczonej młodzieży. Dawane przez niego codzienne świadectwo, pełna dynamizmu obecność i rodzinna atmosfera, jaką stworzył w Oratorium, budziły w młodzieży poczucie współpracy i współodpowiedzialności. Poprzez powstałe przy Oratorium szkoły, troskę o młodych ludzi pochodzących ze środowisk robotniczych, pomoc w zdobyciu miejsca pracy, współpracę z rządem, wydawnictwa książko-

fikowania działań na «miarę człowieka» i możliwości sytuacji w których się znajdują. Chodzi o poszukiwanie trudnej równowagi między radykalnymi propozycjami sensu (które mogą przekraczać granice ludzkiego subiektywizmu i społeczno-kulturowego doświadczenia jednostki) i szacunkiem dla osobistej i wspólnotowej dynamiki osoby". (C. Nanni, Ksiqdz Bosko wczoraj i dziś. Salezjańska pedagogika dzisiaj, [w:] Ksiadz Bosko i jego system wychowawczy, red. J. Niewęgłowski, Warszawa 2000, s. 259.

14 P. Chavez Villanueva, Wychowujemy z sercem Księdza Bosko... Wiazanka 2008. Komentarz Przełożonego Generalnego Towarzystwa Salezjańskiego, thum. P. Szelag, Kraków 2008, s. 38. 
we i prasowe, różnego rodzaju formy rozrywki chciał nauczyć młodych ludzi odpowiedzialnego radzenia sobie z problemami życia. W ten sposób, obejmując szerokie dziedziny życia młodzieży, potrafił on stworzyć syntezę działalności ewangelicznej i wychowawczej. ${ }^{15}$

W wychowaniu odpowiedzialnego i uczciwego obywatela Jan Bosko zwracał uwagę na wychowawcze towarzyszenie młodzieży w odpowiednim poznawaniu skomplikowanej rzeczywistości społeczno-politycznej. Był przekonany, że znajomość doświadczeń innych wychowawców, analiza uwarunkowań historycznych i przeobrażeń społecznych, stają się wyzwaniami do udzielenia nowych, skuteczniejszych odpowiedzi wychowawczych, by wychowanek mógł uczestniczyć w złożonej i różnorodnej działalności ekonomicznej, społecznej, legislacyjnej, administracyjnej i kulturalnej. ${ }^{16}$ Społeczne znaczenie tak rozumianego wychowania ukazuje Jan Bosko wskazując na własne osiagnięcia. W memorandum adresowanym do ministra spraw wewnętrznych Franciszka Crispi pisał: „Powołując się na trzydzieści pięć lat doświadczenia mogę powiedzieć, że:

1. Wielu chłopców mających za sobą karę więzienia, bez trudności zabrało się do nauki zawodu, dzięki któremu mogli zarobić na swoje utrzymanie.

2. Wielu znajdujących się w niebezpieczeństwie stania się ulicznikami będącymi utrapieniem dla społeczeństwa i źródłem problemów dla władz, zmieniło swoje postępowanie stając się godnymi szacunku obywatelami.

3. Przy pomocy statystyk można stwierdzić, że ponad sto tysięcy młodych ludzi, którzy zetknęli się z tym systemem, nauczyło się muzyko-

15 Por. L. Cian, dz. cyt., s. 180-185; R. Wienschenk, Podstawy pedagogiki Księdza Bosko, thum. J. Jurczyński, Warszawa 1996, s. 81-93. „Chcąc uformować uczciwych obywateli i dobrych chrześcijan, brał pod uwagę wymagania społeczne i kościelne, a nie potrzeby osobistej samorealizacji i zaspokojenie oczekiwań typu egocentrycznego czy po prostu konsumpcyjnego. Formował ludzi dla społeczeństwa otwartego, autentycznego, które rodzi dojrzałość osoby i sprzyja szczęściu". (S. De Pieri, Ukierunkowanie $w$ wychowaniu i towarzyszenie powołaniu, Warszawa 2002, s. 61.).

16 Por. J. Bosko, Wspomnienia oratorium, thum. I. Gutewicz, Warszawa 1987, s. 185-186; C. Bissoli, dz. cyt., s. 43-48. 
wania, korzystania z literatury, rzemiosła lub handlu. W następstwie tego stali się oni zdolnymi rzemieślnikami, właścicielami sklepów, urzędnikami, nauczycielami. Liczni zajęli wysokie stanowiska w armii. Wielu łobuzów obrało karierę naukową zdobywając tytuły uniwersyteckie w dziedzinie literatury, matematyki, prawa, architektury. Inni z kolei stali się notariuszami, aptekarzami, itd."17

Zaangażowany i odpowiedzialny obywatel przez swoje słowa i czyny przyczynia się do rozwoju życia publicznego i społecznego. „Klasyczna formuła ks. Bosko zawiera konotacje, które nadają jej i dzisiaj aktualny charakter. (...) Współczesny uczciwy obywatel jest osobą, która uczestniczy w dynamikach demokracji; jest krytyczny, ponieważ żyjemy w społeczeństwie pluralistycznym i pełnym przesłań." ${ }^{18}$ Dzisiejsza panorama społeczna, polityczna i ekonomiczna ukazuje nam społeczeństwo zglobalizowane, ale również naznaczone wieloma konfliktami, nierównością i niesprawiedliwością. Jesteśmy świadkami stylów życia charakteryzujących się bardziej wykluczeniem niż włączeniem, bardziej brakiem poczucia bezpieczeństwa niż harmonijnym współżyciem. Wszystko to domaga się takiego wychowania, które umożliwi pełny rozwój społeczeństwu jako całości, jak i poszczególnym jego członkom. Wychowanie ze swej natury jest działaniem skierowanym na przyszłość. „W tak opisanym kontekście należy mieć na względzie następujące kierunki wychowawczego oddziaływania:

a) budzenie krytycznej czujności oraz troski o tożsamość kulturową;

b) dokonywanie ponownej refleksji nad podstawowymi kategoriami dotyczącymi egzystencji osoby i społeczności (czas, historia, tożsamość społeczna, transcendencja itp.);

c) troszczenie się o ludzką jakość (humanitas) życia i osobową tożsamość;

\footnotetext{
17 R. Wienschenk, dz. cyt., s. 93-94.

18 J. E. Vecchi, Strażnicy marzeń..., dz. cyt., s. 156. „W szczególności oznaczać to będzie uświadomienie sobie historycznych potrzeb, wymagań, aspiracji i niespełnionych oczekiwań, które domagają się spełnienia (...) dla «bycia więcej», dla «lepszego życia», «lepszej ludzkości», «lepszej jakości życia» wszystkich i każdego z osobna. Życie dobre i w pełni jest celem ostatecznym każdego wychowania". (C. Nanni, Ksiqdz Bosko wczoraj i dziś..., dz. cyt., s. 257.).
} 
d) motywowanie i praktykowanie «złożonego obywatelstwa» (które łączy w sobie odpowiednio to, co lokalne, narodowe, międzynarodowe i światowe);

e) wychowanie do przezwyciężania fundamentalizmu religijnego;

f) wychowanie do wielkiego serca zdolnego do przebaczenia i wdzięczności." 19

Jan Bosko zaczynał od tego, co było możliwe, biorąc pod uwage rozwój i osobowość młodego człowieka oraz zaistniałą sytuację wychowawczą. Interesował się całym jego życiem rozpoznając potrzeby i domyślając się tych najbardziej ukrytych. W jego oratorium wychowanek stawał się współtwórcą własnego rozwoju. Wskazywał, że wychowawca powinien trzymać się specyficznej drogi pedagogicznej, która z jednej strony precyzuje dynamikę rozwojową ludzkich sprawności, z drugiej zaś kształtuje w młodzieży warunki do udzielenia swobodnej i stopniowej na nią odpowiedzi. „Pedagogia Księdza Bosko - jak stwierdza P. Braido - utożsamia się z całym jego działaniem, a całe działanie z jego osobowością. Cały zaś Ksiądz Bosko, zawiera się ostatecznie w jego sercu." 20 System ten przeszedł do historii i ci, którzy na nim oparli swą własną pracę wychowawczą, zdają sobie sprawę, iż jest on jedyną metodą pozwalająca na stworzenie pełnego człowieka, na wykształcenie uczciwego obywatela i zaangażowanego chrześcijanina.

19 F. Casella, Wychowywać do poszanowania praw człowieka w wierności systemowi edukacyjnemu św. Jana Bosko, [w:] Wychowanie w stużbie praw człowieka, red. J. Gocko, R. Sadowski, Warszawa 2008, s. 146.

20 P. Braido, Prevenire non reprimere. Il sistema educativo di Don Bosco, Roma 1999, s. 181. Zatem w perspektywie sytemu prewencyjnego księdza Bosko, „być uczciwym obywatelem oznacza dziś dla młodego człowieka:

a) działać na rzecz godności człowieka i jego praw we wszystkich kontekstach;

b) żyć szlachetnie w rodzinie i przygotować się do tworzenia jej na bazie wzajemnego obdarowywania;

c) wspierać solidarność, zwłaszcza w stosunku do najuboższych;

d) uczciwie i kompetentnie rozwijać własną pracę;

e) działać na rzecz sprawiedliwości, pokoju i wspólnego dobra w polityce;

f) szanować twórczość;

g) wspierać kulturę”. (Eduacare i giovani alla fede. Documenti Capitolari, „Atti del Consiglio Generale della Società salesiana di San Giovanni Bosco” 333 (1990), s. 111. 


\section{PODSUMOWANIE}

Dzisiejsza panorama społeczna, polityczna i ekonomiczna ukazuje nam społeczeństwo zglobalizowane, ale również naznaczone licznymi konfliktami (o mniejszym lub większym zasięgu, zawsze jednak pełnymi destrukcji, przemocy), nierównością i niesprawiedliwością. Wszystko to wymaga, by - jak stwierdza J. Vecchi - „wychowywać ich i wychowywać siebie, przyjmując i prosząc o pomoc młodych, rozbudzając w nich odpowiedzialność za swoich rówieśników, promując postępowania pedagogiczne, które nadadzą sens i kierunek ich życiu, będą kształtowały świadomość, wychowanie do miłości i solidarności. (...) Chodzi więc o tworzenie kultury skierowanej na drugiego człowieka." ${ }^{21}$ Tym samym, według pedagogicznego programu księdza Bosko, wychowawca powinien jednocześnie zająć się obywatelską (społeczną), moralną i intelektualną formacją młodzieży. Był przekonany, że kto daje dobre wychowanie, ten wpływa na przyszły kształt społeczeństwa.

\section{BIBLIOGRAFIA}

Appi F., Wiara - świeckość - obywatelstwo, thum. T. Żeleźnik, „Społeczeństwo" 2006, nr 4-5, s. 653-666.

Bissoli C., Jan Pawet II o systemie wychowawczym księdza Bosko, thum. K. Misiaszek, Warszawa, Wydawnictwo Salezjańskie 2001.

Bosko J., System prewencyjny w wychowaniu mtodzieży, w: Wspótczesny wychowawca w stylu księdza Bosko, (red.) J. Wilk, Lublin, Poligrafia Inspektoratu Towarzystwa Salezjańskiego 1998, s. 213-219.

Bosko J., Wspomnienia oratorium, tłum. I. Gutewicz, Warszawa, Wydawnictwo Salezjańskie 1987.

Braido P., Prevenire non reprimere. Il sistema educativo di Don Bosco, LAS, Roma 1999.

${ }^{21}$ J. Vecchi, Globalizacja. Na rozdrożu wychowania w miłości, tłum. J. Chapska, Warszawa 2005, s. 23. 
Casella F., L'esperienza educativa preventiva di don Bosco. Studi sull'educatione salesiana fra tradicione e modernità, Roma, LAS 2007.

Casella F., Wychowywać do poszanowania praw czlowieka w wierności systemowi edukacyjnemu św. Jana Bosko, [w:] Wychowanie w stużbie praw czlowieka, (red.) J. Gocko, R. Sadowski, Warszawa, Towarzystwo Naukowe Franciszka Salezego 2008, s. 113-147.

Cian L., System zapobiegawczy św. Jana Bosko i charakterystyczne rysy jego stylu, thum. M. Gabryel, Warszawa, Wydawnictwo Salezjańskie 1986.

Cian L., Wychowanie w duchu Księdza Bosko, tłum. I. Gutewicz, Warszawa, Wydawnictwo Salezjańskie 1990.

Dańkowski D., Obywatel, w: Słownik społeczny, (red.) B. Szlachta, Kraków, Wydawnictwo WAM 2004, s. 765-775.

De Pieri S., Ukierunkowanie w wychowaniu i towarzyszenie powołaniu, Warszawa, Wydawnictwo Salezjańskie 2002.

Eduacare $i$ giovani alla fede. Documenti Capitolari, „Atti del Consiglio Generale della Società salesiana di San Giovanni Bosco" 333(1990).

Fontana U., Relacja sekretem wszelkiego wychowania, thum. J. Krykowski, Warszawa, Wydawnictwo Salezjańskie 2002.

Jan Paweł II, List ,Juvenum patris” w setna rocznicę śmierci św. Jana Bosco, Rzym, Tipografia Poliglotta Vaticana 1988.

Nanni C., Ksiadz Bosko wczoraj i dziś. Salezjańska pedagogika dzisiaj, w: Ksiadz Bosko i jego system wychowawczy, red. J. Niewęgłowski, Warszawa, Wydawnictwo Salezjańskie 2000, s. 251-263.

Potulicka E., Edukacja dla demokracji, w: Wychowanie. Pojęcia - Procesy - Konteksty. Interdyscyplinarne ujęcie, t. 2, red. M. Dudzikowa, M. Czerepaniak-Walczak, Gdańsk, Wydawnictwo GWP 2007, s. 83-104.

T. Ślipko, Zarys etyki ogólnej, Kraków, Wydawnictwo Apostolstwa Modlitwy 1974.

Vecchi J. E., Strażnicy marzeń z palcem na myszce. Wychowawcy $w$ dobie informatyki, tłum. A. Lis, Warszawa, Wydawnictwo Salezjańskie 2001 . 
Vecchi J. E., Globalizacja. Na rozdrożu wychowania w miłości, thum. J. Chapska, Warszawa, Wydawnictwo Salezjańskie 2005.

Weinschenk R., Podstawy pedagogiki Księdza Bosko, tłum. J. Jurczyński, Warszawa, Wydawnictwo Salezjańskie 1996.

Wojtyła K., Osoba i czyn oraz inne studia antropologiczne, Lublin, Wydawnictwo Towarzystwa Naukowego KUL 1994. 